\title{
ERRATUM
}

\section{Erratum to: The effect of inherited thrombophilia on second trimester combined aneuploidy screening test markers}

\author{
Muzaffer Seyhan Cıkman • Kerem Doga Seckin • \\ Mehmet Fatih Karslı • Eralp Baser • \\ Duygu Ilke Cıkman • Mahmut Nedim Cicek
}

Published online: 11 October 2014

(c) Springer-Verlag Berlin Heidelberg 2014

\section{Erratum to: Arch Gynecol Obstet}

\section{DOI 10.1007/s00404-014-3468-1}

We regret a typo error in the official publication of Abstract, results section's patient number. In this section, the second line patient number should read as 262 instead of 26. The correct sentence is given below.

Among these, 262 women met the criteria of thrombophilia.

The online version of the original article can be found under doi:10.1007/s00404-014-3468-1.

M. S. Cikman · K. D. Seckin (凹) · M. F. Karslı · E. Baser · M. N. Cicek

Department of Obstetrics and Gynecology, Zekai Tahir Burak Women's Health Education and Research Hospital, Altindag, Ankara, Turkey

e-mail: doga_seckin@hotmail.com

D. I. C1kman

Department of Internal Medicine, Hacettepe University Hospital,

Ankara, Turkey 